\title{
HUBUNGAN PENGETAHUAN TENTANG COVID-19 TERHADAP SIKAP STIGMA MASYARAKAT PADA ORANG YANG BERSINGGUNGAN DENGAN COVID-19
}

\author{
Nuril Endi Rahman ${ }^{1}$, Anita Wijayaningtyas Utami ${ }^{2}$, Annisa Nadhilah ${ }^{3}$ \\ ${ }^{1}$ Program Studi IImu Kesejahteraan Sosial FISIP Universitas Muhammadiyah Madiun \\ 2,3 Serat Publisher \\ 1nuril.endy@gmail.com, 2anittaumi@gmail.com, 33nadhilahannisa@gmail.com
}

\begin{abstract}
ABSTRAK
Maraknya informasi yang bergulir mengenai Covid-19 sebagai pembentuk pengetahuan masyarakat, rentan memunculkan stigma negatif terhadap orang-orang yang bersinggungan dengan Covid-19. Penelitian survei ini adalah penelitian cross-sectional kuantitatif melibatkan 101 responden yang bertujuan untuk melihat hubungan antara tingkat pengetahuan tentang Covid-19 dan sikap stigma terhadap orang-orang yang bersinggungan dengan Covid-19. Hasil penelitian yang dilakukan pada masyarakat Yogyakarta yang sempat melakukan blokade pemukiman menunjukkan bahwa $78.2 \%$ tingkat pengetahuan tentang Covid-19 berkategori baik dan $21.8 \%$ berkategori cukup. Tingkat stigma mendapati hasil 63.4\% memiliki sikap stigma cukup tinggi dan $33.7 \%$ memiliki sikap stigma tinggi. Adapun hasil analisis terhadap kedua variabel diketahui bahwa $47,5 \%$ responden dengan tingkat pengetahuan tentang Covid-19 berkategori baik, memiliki sikap stigma tergolong cukup tinggi. Namun, dari hasil uji Chi-Square diperoleh kesimpulan bahwa tidak terdapat hubungan antara tingkat pengetahuan tentang Covid-19 dengan sikap stigma masyarakat Yogyakarta terhadap orang-orang yang bersinggungan dengan Covid-19. Sikap stigma yang muncul adalah faktor dari kesalahpahaman dalam menerima informasi mengenai bahaya dan penularan Covid-19.
\end{abstract}

Kata kunci: Covid-19, Informasi, Pengetahuan dan Stigma

\begin{abstract}
The spread of information about Covid-19 as a form of public knowledge is prone to create a negative stigma against people who come into contact with Covid-19. This survey research is a quantitative cross-sectional study involving 101 respondents aiming to see the relationship between the level of knowledge about Covid-19 and stigma attitudes towards people who intersect with Covid-19. The results of research conducted on the people of Yogyakarta who had a settlement blockade showed that $78.2 \%$ of the level of knowledge about Covid-19 was in the good category and $21.8 \%$ was in the sufficient category. The level of stigma found that $63.4 \%$ had a fairly high stigma attitude and $33.7 \%$ had a high stigma attitude. The results of the analysis of the two variables show that $47.5 \%$ of respondents with a good level of knowledge about Covid-19, have a fairly high stigma attitude. From the results of the Chi-Square test, it was concluded that there was no relationship between the level of knowledge about Covid-19 and the stigma attitudes of the people of Yogyakarta towards people who intersect with Covid-19. The stigma that emerges is a factor of misunderstanding in receiving information about the dangers and transmission of Covid-19.
\end{abstract}

Key words: Covid-19, Information, Knowledge and Stigma 


\section{PENDAHULUAN}

Pandemi Covid-19 merupakan wabah global yang bermula di Provinsi Wuhan-China bulan Desember 2019, kemudian menyebar cepat ke berbagai belahan dunia. Indonesia tergolong negara dengan angka keterjangkitan Covid-19 tertinggi di Asia Tenggara. Pertambahan jumlah pasien positif di Indonesia, sangat signifikan sejak kasus 01 dan kasus 02 diumumkan pada 2 Maret 2020. KOMPAS.com melansir, terdapat 45.029 kasus positif, 17.883 sembuh dan 2.429 meninggal per 20 Juni 2020. Kondisi ini menunjukkan bahwa upaya penanganan pandemi harus lebih intens dan membutuhkan keterlibatan semua pihak.

Daerah Istimewa Yogyakarta (DIY) termasuk wilayah yang tidak dikategorisasikan sebagai zona merah, tetapi tidak kemudian menjadikan DIY sebagai zona aman Covid-19. Persebaran Covid-19 melekat dengan mobilitas manusia. Masyarakat setempat, sempat memblokade permukimannya dengan portal. Meskipun demikian, kasus konfirmasi positif Covid-19 di DIY masih menunjukkan kenaikan. Data situs Pemda Yogyakarta per 20 Juni 2020, jumlah pasien positif 285 orang dengan 231 diantaranya.

\section{Pengetahuan Tentang Bahaya Penyakit Menular}

Pegetahuan berperan penting membangun strategi menghadapi krisis kesehatan, termasuk pada masa pandemi Covid-19 ini. Pengetahuan atas karakteristik Covid-19, sangat dipengaruhi oleh akses informasi masyarakat. Beberapa aspek potensial pemicu kesenjangan komunikasi dalam mempersiapkan dan merespon saat pandemi influenza, yaitu karakteristik sosiodemografis (umur, ras dan etnis), faktor kepercayaan (keseriusan penerimaan), dan pengaruh komunikasi (pemberitaan media, informasi kebiasaan masyarakat dan level pengetahuan tentang ancaman) (Lin dkk, 2014). Oleh karenanya, penduduk yang hidup di lingkungan masyarakat dengan status sosial ekonomi tinggi (SSE tinggi), kemungkinan memiliki akses informasi yang lebih baik tentang ancaman kesehatan masyarakat dibandingkan dengan penduduk di lingkungan status sosial ekonomi rendah, dan individu dengan SSE tinggi kemungkinan lebih dapat mengkombinasikan pesan komunikasi kesehatan penting untuk mengambil tindakan efektif berdasarkan pengukuran pencegahan yang direkomendasikan pihak-pihak terkait (McCauley dkk, 2013).

Berbagai sosialisasi mengenai Pola Hidup Bersih dan Sehat (PHBS) yang bertujuan mencegah penularan Covid-19 dari pemerintah seharusnya menjadi arus informasi utama bagi masyarakat. Namun, di era social media ini, arus informasi bisa datang dari berbagai penjuru dan sulit dikontrol. Masyarakat dapat mengakses berbagai informasi mengenai Covid-19, dimana kebenaran informasi tersebut tidak dapat dipertanggungjawabkan. Padahal, dari informasi yang keliru dapat membentuk pengetahuan yang keliru. Sementara, sebagian masyarakat masih abai mengakses informasi mengenai Covid-19, dimana minimnya informasi akan membentuk rendahnya tingkat pengetahuan tentang Covid19.

Faktor pengetahuan bukan faktor mutlak yang membentuk sikap stigma seseorang. Penelitian Prastiwi (2019) menunjukkan bahwa seseorang dengan pengetahuan baik tentang virus HIV/AIDS, memiliki stigma yang tinggi kepada Orang Dengan HIV/AIDS (ODHA). Sementara, hasil penelitian Astuti (2016) menunjukkan bahwa para bidan berpengetahuan kurang mengenai virus HIV/AIDS, justru memiliki stigma rendah terhadap ODHA. Hasil penelitian Finnajakh (2019) juga menunjukkan bahwa sebagian besar responden yang berpengetahuan kurang baik tentang virus HIV/AIDS, memberikan stigma negatif terhadap ODHA.

Beberapa penelitian tersebut menunjukkan tidak ada hubungan signifikan antara pengetahuan dan sikap stigma. Setiap orang yang memiliki pengetahuan, juga memiliki persepsi yang berbeda mengenai seseorang yang terinfeksi penyakit menular. Dalam konteks fenomena pandemi Covid-19, informasi yang banyak diberikan kepada masyarakat adalah informasi mengenai bahaya dan pencegahan penularan virus Covid-19, dimana bentuk pencegahannya adalah menjaga jarak dengan orang-orang yang terindikasi terinfeksi virus maupun orang yang tidak memiliki gejala sekalipun. Jika seseorang memiliki pengetahuan yang baik terkait pencegahan Covid-19, tetapi kebijaksanaan dan subjektivitas mempengaruhi pandangannya, maka tidak ada filterisasi 
penerimaan informasi dan kebijaksanaan bersikap. Hal demikian menjadikan pengetahuan yang dimiliki berpotensi menjadi pemahaman keliru dan memunculkan persepsi negatif. Apabila persepsi tersebut terbentuk, maka memicu stigma negatif terhadap orangorang yang bersinggungan dengan Covid- 19 .

\section{Stigma}

Stigma merupakan pandangan negatif
kepada seseorang atau sekelompok masyarakat. Pada kondisi pandemi Covid-19, stigma lebih diarahkan pada pandangan atas kondisi fisik seseorang yang mengalami gangguan akibat terinfeksi virus. Erving Goffman (1963:1) membagi stigma kedalam 3 tipe yakni: 1) Stigma yang berhubungan dengan kecacatan pada tubuh seseorang; 2) Stigma yang berkaitan dengan kerusakankerusakan karakter individu atau penyimpangan-penyimpangan perilaku; serta 3) Stigma yang berhubungan dengan suku, ras, dan agama. Kipp et.al (dalam Hidayati, 2015:80) menggambarkan stigma sebagai proses sosial atau pengalaman pribadi ditandai dengan pengucilan, celaan dan devaluasi, karena anggapan sosial yang merugikan tentang individu maupun kelompok dikarenakan permasalahan kesehatan tertentu. Dalam konteks pandemi Covid-19, stigma merupakan ancaman besar ketika seseorang yang dinyatakan positif terinfeksi Covid-19 terlanjur diberi label sebagai seorang pembawa penyakit dan membahayakan bagi orang-orang disekitarnya, sehingga seorang pasien berpotensi mengalami devaluasi atau pengucilan dalam jangka waktu lama.

\section{METODE}

Penelitian ini adalah penelitian kuantitatif berjenis survai dengan desain studi crossectional yang dianalisis secara deskriptif analitik. Penelitian survai adalah penelitian melalui alat pengumpul data pokok berupa kuesioner dengan mengambil sampel untuk mewakili populasi (Singarimbun dan Effendi, 2011:3). Studi crossectional, yakni suatu penelitian untuk mempelajari dinamika korelasi antar variabel sebab atau resiko dan akibat yang terjadi pada objek penelitian yang diukur atau dikumpulkan pada waktu bersamaan (Notoatmodjo, 2010).

Populasi merupakan ide abstrak dari sehimpunan besar kasus, dimana peneliti mengambil sampel dan hasil sampel tersebut digeneralisasikan (Neuman, 2013:270).
Populasi dalam penelitian ini adalah masyarakat Yogyakarta (DIY). Dari populasi tersebut, dilakukan pengambilan sampel dengan teknik sampling kemudahan (convenience sampling) yang merupakan sampel non-acak yang dipilih peneliti dari orang yang kebetulan lewat (Neuman, 2013:271). Sementara, jumlah sampel ditentukan dari rumus $\mathrm{n}=\mathrm{N} /\left(1+\mathrm{N} . \mathrm{Moe}^{2}\right)$, dimana $\mathrm{n}=$ jumlah sampel, $\mathrm{N}=$ jumlah populasi dan Moe $=$ Margin of error maximum (Sutopo, 2010). Dari jumlah penduduk DIY sebanyak 3.842.932 jiwa (BPS, 2020) dan tingkat kesalahan $10 \%$, maka jumlah sampel dalam penelitian ini 101 responden.

Proses pengambilan data yang disesuaikan dengan kondisi pandemi dilaksanakan pada bulan Juni 2020. Peneliti memilih sampel melalui berbagai platform media sosial (WhatsApp, Facebook dan Instagram). Peneliti menyebar link kuesioner ke komunitas-komunitas yang terdiri dari orang-orang yang berdomisili di DIY.

Variabel yang digunakan dalam penelitian ini tingkat pengetahuan masyarakat tentang Covid-19 sebagai variabel bebas dan tingkat stigma terhadap pasien Covid-19 sebagai variabel terikat. Variabel bebas (independent variable) adalah variabel yang mempengaruhi, menyebabkan timbulnya atau berubahnya variabel terikat. Variabel terikat (dependent variable) atau variabel yang dipengaruhi oleh variabel bebas. Pada variabel tingkat pengetahuan terdiri dari 9 item pertanyaan, sedangkan variabel sikap stigma terdiri dari 11 item pertanyaan dalam instrumen.

Pengukuran pada tingkat pengetahuan dikategorikan menjadi 3 yakni: 1) Pengetahuan baik apabila hasil persentase nilai responden $>80 \%$; 2) Pengetahuan cukup apabila hasil persentase nilai responden $60-80 \%$; dan 3 ) Pengetahuan kurang jika hasil persentase nilai responden $<60 \%$. Sedangkan pada variabel sikap stigma dikategorikan kedalam tiga tingkatan yakni: 1) Stigma rendah apabila hasil persentase responden $<60 \%$; 2) Stigma cukup jika hasil persentase responden $60-80 \%$; dan 3) Stigma tinggi jika hasil persentase nilai responden $>80 \%$. Dengan melihat perolehan skor dari variabel tingkat pengetahuan tersebut, maka dilihat seberapa besar signifikansi hubungan pengetahuan masyarakat tentang Covid-19 terhadap sikap stigma. 
Analisis data dalam penelitian ini menggunakan perangkat lunak SPSS Versi 24. Analisis yang digunakan adalah analisis univariat, bivariat dan bivariat kontrol. Analisis univariat untuk melihat distribusi responden dari masing-masing variabel, analisis bivariat kontrol untuk melihat stigma berdasarkan karakteristik responden, sedangkan analisis bivariat digunakan untuk melihat hubungan antara variabel bebas dan variabel terikat menggunakan uji chi square dengan taraf signifikansi $95 \%$. Variabel dapat dikatakan berhubungan secara signifikan jika nilai $p<0.05$. Analisa data dalam penelitian ini juga didukung analisa deskriptif, yaitu analisa yang dilakukan tidak untuk menguji hipotesis dan hanya memberikan informasi mengenai data yang diamati dengan mengeksplorasi karakteristik data, meringkas dan mendeskripsikan data (Purwanto dan Sulistiyastuti, 2011:109). Analisis deskriptif bertujuan untuk mengklarifikasi hasil analisis berupa angka, serta menjelaskan dinamika korelasi antar variabel.

\section{HASIL DAN PEMBAHASAN}

Karakteristik Responden

Penelitian ini melibatkan secara keseluruhan 101 responden yang merupakan masyarakat Yogyakarta dengan karakteristik cukup beragam dari sisi usia, tingkat pendidikan, jenis pekerjaan dan tingkat pendapatan. Dari sisi usia, mayoritas merupakan generasi muda berusia 17-25 tahun dengan persentase $56.4 \%$ atau 57 responden dan usia 26-35 tahun sejumlah $30.7 \%$ atau 31 responden. Terdapat pula 1 responden berusia 56-65 tahun. Sementara, dari aspek tingkat pendidikan, jenis pekerjaan dan tingkat pendapatan, responden dicatat berkecenderungan tingkat pendidikan menengah dan tinggi, tetapi belum/tidak bekerja dan belum/tidak memiliki pendapatan.

Pengetahuan Masyarakat Tentang Covid-19 dan Sikap Stigma Terhadap Orang Positif Covid-19

Hasil penelitian menunjukkan bahwa hampir separuh responden, yaitu $47.5 \%$ atau 48 responden memiliki pengetahuan yang baik tentang Covid-19 meliputi penularan antar sesama manusia, dan upaya-upaya pencegahan terjangkit Covid-19. Namun, para responden memiliki sikap stigma dengan kategori cukup tinggi terhadap mantan penderita dan penderita Covid-19. Sementara,
$27.7 \%$ atau 28 responden dengan pengetahuan baik, memiliki sikap stigma tinggi. Responden yang memiliki pengetahuan tinggi tentang Covid-19 dengan sikap stigma kurang, sebesar $3.0 \%$ atau 3 responden.

Hasil ini sejalan dengan penelitian Park (2012) dan Guma (2011), dimana semakin banyak informasi yang diterima oleh seseorang, semakin banyak pula pengetahuan yang didapatkan mengenai bahaya dan cara penularan HIV/AIDS. Dalam hal ini para responden yang memiliki pengetahuan tentang bahaya Covid-19 dan penularannya, akibat banyak menerima informasi dari media mainstream maupun media sosial. Namun, sejalan dengan hasil penelitian Urifah (2017) dan Prastiwi (2019), bahwa stigma masyarakat masih cukup tinggi terhadap orang-orang yang terinfeksi penyakit menular seperti HIV/AIDS dikarenakan sebagian besar masyarakat masih memiliki persepsi negatif terhadap ODHA.

Tabel 1 Tingkat Pengetahuan dan Tingkat Stigma

\begin{tabular}{crrrr}
\hline \multirow{2}{*}{$\begin{array}{c}\text { Pengeta } \\
\text { huan }\end{array}$} & \multicolumn{3}{c}{ Stigma COVID 19 } & \multirow{2}{*}{ Total } \\
\cline { 2 - 4 } & \multicolumn{1}{c}{ T } & \multicolumn{1}{c}{ C } & \multicolumn{1}{c}{ K } & \\
\hline Baik & 28 & 48 & 3 & 79 \\
$\%$ & 27,7 & 47,5 & 3,0 & 78,2 \\
\hline Cukup & 6 & 16 & 0 & 22 \\
$\%$ & 5,9 & 15,8 & 0,0 & 21,8 \\
\hline Total & 34 & 64 & 3 & 101 \\
$\%$ & 33,7 & 63,4 & 3 & 100 \\
\hline Sumber: Hasil Olah Data Peneliti $(2020)$ &
\end{tabular}

Berdasarkan uji Chi-Square dengan menggunakan Pearson Chi-Square, diperoleh taraf signifikansi $p>0.05$, sehingga diketahui bahwa tidak terdapat hubungan signifikan antara pengetahuan tentang Covid-19 dengan sikap stigma terhadap orang-orang yang bersinggungan dengan Covid-19. Faktor penyebab tidak berpengaruhnya pengetahuan yang dimiliki masyarakat dengan sikap stigma adalah pemahaman yang keliru atas informasi yang diperoleh. Tampak bahwa salah satu upaya pencegahan penularan Covid-19 rekomendasi WHO dengan menjaga jarak antar manusia disalah artikan, terlebih pada orang-orang yang bersinggungan dengan Covid-19, sehingga menyebabkan seseorang dengan pengetahuan tinggi mengenai Covid19 , cenderung memiliki sikap stigma cukup terhadap orang-orang yang bersinggungan dengan Covid-19. Hal ini senada dengan hasil 
penelitian Baroya (2017), serta Hesty dan Suherni (2015) yang juga menemukan bahwa tingkat pengetahuan masyarakat tentang bahaya penyakit menular HIV/AIDS, tidak bermakna secara signifikan dalam faktor predisposisi terhadap sikap stigma kepada Orang Dengan HIV/AIDS (ODHA).

\section{Sikap Stigma Berdasarkan Usia}

Mayoritas responden yang berada di usia muda dengan usia 17-25 tahun dan 26-35 tahun dengan memiliki sikap stigma tinggi dan cukup. Dari keseluruhan $97.1 \%$ atau 98 responden dengan stigma tinggi dan cukup, $84.1 \%$ atau 85 responden adalah responden direntang usia muda tersebut. Persentase tertinggi, yaitu $35.6 \%$ atau 36 responden dengan kategori usia 17-25 tahun, memiliki sikap stigma cukup dan $19.8 \%$ atau 20 responden memiliki sikap stigma tinggi. Pada rentang usia 26-35 tahun, $18.8 \%$ atau 19 responden memiliki stigma cukup dan 9.9\% atau 10 responden memiliki sikap stigma tinggi. Sementara, 1 responden dengan usia antara 56-65 tahun memiliki sikap stigma cukup.

Tabel 2 Umur dan Tingkat Stigma

\begin{tabular}{crrrr}
\hline Kategori & \multicolumn{3}{c}{ Stigma COVID 19 } & \multicolumn{2}{l}{ Total } \\
\cline { 2 - 5 } (th) & \multicolumn{1}{c}{ T } & \multicolumn{1}{c}{ C } & \multicolumn{1}{l}{ R } & \multicolumn{1}{l}{. } \\
\hline \multirow{2}{*}{$17-25$} & 20 & 36 & 1 & 57 \\
& $19.8 \%$ & $35.6 \%$ & $1.0 \%$ & $56.4 \%$ \\
$26-35$ & 10 & 19 & 2 & 31 \\
$36-45$ & $9.9 \%$ & $18.8 \%$ & $2.0 \%$ & $30.7 \%$ \\
& 2 & 0 & 0 & 2 \\
$46-55$ & $2.0 \%$ & $0.0 \%$ & $0.0 \%$ & $2.0 \%$ \\
& 2 & 8 & 0 & 10 \\
$56-65$ & $2.0 \%$ & $7.9 \%$ & $0.0 \%$ & $9.9 \%$ \\
& 0 & 1 & 0 & 1 \\
& $0.0 \%$ & $1.0 \%$ & $0.0 \%$ & $1.0 \%$ \\
\hline Total & 34 & 64 & 3 & 101 \\
& $33.7 \%$ & $63.4 \%$ & $3.0 \%$ & $100.0 \%$
\end{tabular}

Sumber: Hasil Olah Data Peneliti (2020)

\section{Sikap Stigma Berdasarkan Pendidikan}

Persentase sikap stigma dengan kategori cukup sebesar $63.4 \%$ atau 64 responden, dimana $44.5 \%$ atau 45 responden berlatarbelakang tingkat pendidikan SMA/SMK dan S1. Nilai tersebut diperoleh dari $25.7 \%$ atau 26 responden adalah lulusan SMA/SMK dan $18.8 \%$ atau 19 responden berpendidikan S1. Sementara, $33.7 \%$ atau 34 responden dengan sikap stigma berkategori tinggi tampak bahwa $15.8 \%$ atau 16 responden merupakan lulusan S1 dan $12.9 \%$ atau 13 responden adalah tamatan SMA/SMK. Hal yang menarik, yaitu responden dengan pendidikan relatif rendah yaitu SD dan SMP dengan persentase $5 \%$ atau 5 responden, secara keseluruhan memiliki sikap stigma cukup.

Tabel 3 Tingkat Pendidikan dan Tingkat Stigma

\begin{tabular}{crrrr}
\multirow{2}{*}{ Kategori } & \multicolumn{2}{c}{ Stigma COVID 19 } & \multirow{2}{*}{ Total } \\
\cline { 2 - 5 } & \multicolumn{1}{c}{ T } & \multicolumn{1}{c}{ C } & \multicolumn{1}{c}{ K } & \\
\hline \multirow{2}{*}{ SD } & 0 & 2 & 0 & 2 \\
& $0.0 \%$ & $2.0 \%$ & $0.0 \%$ & $2.0 \%$ \\
SMP & 0 & 3 & 0 & 3 \\
& $0.0 \%$ & $3.0 \%$ & $0.0 \%$ & $3.0 \%$ \\
SMA/ SMK & 13 & 26 & 1 & 40 \\
& $12.9 \%$ & $25.7 \%$ & $1.0 \%$ & $39.6 \%$ \\
D1/D2/D3 & 1 & 4 & 0 & 5 \\
& $1.0 \%$ & $4.0 \%$ & $0.0 \%$ & $5.0 \%$ \\
S1 & 16 & 19 & 2 & 37 \\
& $15.8 \%$ & $18.8 \%$ & $2.0 \%$ & $36.6 \%$ \\
S2 & 4 & 10 & 0 & 14 \\
& $4.0 \%$ & $9.9 \%$ & $0.0 \%$ & $13.9 \%$ \\
\hline \multirow{2}{*}{ Total } & 34 & 64 & 3 & 101 \\
& $33.7 \%$ & $63.4 \%$ & $3.0 \%$ & $100.0 \%$ \\
\hline \multicolumn{2}{c}{ Sumber: } & \multicolumn{4}{l}{ Hasil Olah Data Peneliti $(2020)$}
\end{tabular}

\section{KESIMPULAN DAN SARAN}

Masyarakat Yogyakarta memiliki tingkat pengetahuan tentang Covid-19 yang tergolong baik dan cukup, dimana $78.2 \%$ berkategori baik dan $21.8 \%$ berkategori cukup. $\mathrm{Hal}$ ini berkenaan dengan kemudahan akses informasi yang menjadikan tidak lagi terdapat masyarakat berpengetahuan kurang. Namun, kurangnya kemampuan dalam mengolah berbagai informasi tentang penularan dan bahaya Covid-19 untuk mengambil tindakan efektif, menjadikan terbangun stigma negatif terhadap orang yang bersinggungan dengan Covid-19. Tingkat stigma dicatat berkategori cukup dan tinggi, yakni $97.1 \%$ dengan perincian $63.4 \%$ memiliki sikap stigma cukup tinggi dan $33.7 \%$ memiliki sikap stigma tinggi. Adapun hasil analisis terhadap kedua variabel diketahui bahwa 47,5\% responden dengan tingkat pengetahuan tentang Covid-19 berkategori baik, memiliki sikap stigma tergolong cukup. Sementara, hasil uji ChiSquare diperoleh taraf signifikansi $p>0.05$, sehingga tidak terdapat hubungan antara tingkat pengetahuan tentang Covid-19 dengan sikap stigma masyarakat Yogyakarta terhadap orang-orang yang bersinggungan dengan Covid-19. 
Keterlibatan semua pihak mutlak dibutuhkan dalam menghadapi pandemi Covid19. Pada konteks informasi, pengetahuan dan sikap masyarakat, dibutuhkan kontribusi pemerintah, media massa dan para jurnalis, institusi-instusi kesehatan dan institusi-institusi terkait lain maupun masyarakat sendiri dalam menyebarluaskan informasi yang memiliki validitas dan kredibel terkait Covid-19. Hal demikian penting dilakukan, mengingat sebagian masyarakat masih belum memiliki kemampuan mengelola informasi yang bergulir. Sementara, peran-serta masyarakat untuk mengambil tindakan efektif mengikuti protokol kesehatan pencegahan penularan Covid-19 yang direkomendasikan pihak-pihak terkait menjadi aspek kunci. Keterlibatan semua pihak dalam menyediakan informasi yang memiliki validitas dan kredibel terkait Covid-19 tersebut membantu masyarakat membangun pegetahuan yang tepat dan mengambil tindakan yang sesuai.

\section{UCAPAN TERIMA KASIH}

Artikel ini merupakan hasil penelitian secara daring kepada masyarakat yang berdomisili di DIY melalui berbagai platform media sosial (Whatsapp, Facebook, dan Instagram). Penulis menyampaikan terima kasih kepada para responden yang telah bersedia mengisi kuesioner, sehingga penelitian ini dapat dituliskan menjadi artikel ilmiah.

\section{DAFTAR PUSTAKA}

Astutui, Dwi. 2016. Faktor-Faktor Yang Mempengaruhi Stigma Mahasiswa Kebidanan Terhadap ODHA di Kudus. The 4 University Research Coloquium

Baroya, Ni'mal. 2017. Prediktor Sikap Stigma dan Diskriminasi Terhadap Orang Dengan HIV/AIDS di Kabupaten Jember. Jurnal IKESMA. Vol.13 No. 2 September 2017

Finnajakh, Aunana. 2019. Hubungan Tingkat Pengetahuan dan Persepsi Dengan Stigma Masyarakat Terhadap ODHA di Desa Pandowoharjo, Kecamatan Sleman, Kabupaten Sleman. Publikasi Artikel Skripsi. Prodi Sarjana Terapan Kebidanan, Polteknik Kesehatan Kementerian Kesehatan Yogyakarta.

Goffman, Erving. 1963. STIGMA Notes on The Management of Spoiled Identity. USA: Practice-Hall, Inc. 1963
Guma, J.A. Health Workers Stigmatise HIV and AIDS Patients. South Sudan Medical Journal. 2011:4: 92-3

Hidayati, Eni. 2015. Pengetahuan Dan Stigma Masyarakat Terhadap TBC Setelah Diberikan Pendidikan Kesehatan dan Pencegahan Penularan. Jurnal Keperawatan Soedirman. Vol.10, No.2 Juli 2015

Kipp, A.M et.al. 2011. Socio-demographic and AIDS-Related Factors Associated with Tuberculosis Stigma in Southern Thailand: A Quantitative, Cross-sectional Study of Stigma Among Patients with TB and Healty Community Members. BMC Public Health, 11,675

Kompas. (2020, 6 8). Update Virus Corona di Asean: Indonesia Posisi Kedua Kasus Terbanyak Setelah Singapura Artikel ini telah tayang di Kompas.com dengan judul "Update Virus Corona di Asean: Indonesia Posisi Kedua Kasus Terbanyak Setelah Singapura", Retrieved from Kompas.com: https://www.kompas.com/tren/read/2020/ 06/08/151300865/update-virus-corona-diasean--indonesia-posisi-kedua-kasusterbanyak

Lin Leesa, Elena Savoia, Foluso Agboola dan Kasisomayajula Viswanath. 2014. What Have We Learned about Communication Inequalities during The H1N1 Pandemic: A Systematic Review of The Literature dalam BMC Public Health

McCauley, Michael, Sara Minsky dan Kasisomayajula Viswanath. 2013. The H1N1 Pandemic: Media Frames, Stigmatization and Coping dalam BMC Public Health

Notoatmodjo, S. 2005. Metodologi Penelitian Kesehatan. Jakarta: PT Rieneka Cipta

Neuman, Lawrance. 2013. Metodologi Penelitian Sosial: Pendekatan Kualitatif dan Kuantitatif. Jakarta: Indeks

Pemerintah Daerah. Yogyakarta, Humas. Diakses dari https://corona.jogjaprov.go.id/datastatistik

Purwanto, Erwan Agus dan Dyah Ratih Sulistyastuti. 2011. Metode Penelitian Kuantitatif untuk Administrasi Publik dan Masalah-Masalah Sosial. Yogyakarta: Gava Media

Prastiwi, Wahyu N.R. 2019. Hubungan Pengetahuan, Sikap dan Persepsi Anggota WPA Tentang HIV/AIDS Deangan Stigma Pada ODHA Di Surakarta. Publikasi Artikel 


\begin{tabular}{|c|c|c|c|c|}
\hline Share: Social Work Jurnal & VOLUME: 10 & NOMOR: 2 & HALAMAN: $209-215$ & $\begin{array}{c}\text { ISSN: 2339-0042 (p) } \\
\text { ISSN: 2528-1577 (e) } \\
\text { DOI: 10.24198/share.v10i2.29614 }\end{array}$ \\
\hline
\end{tabular}

Skripsi. Fakultas Ilmu Kesehatan, Universitas Muhammadiyah Surakarta.

Situmeang, Berliana dkk. 2017. Hubungan Pengetahuan HIV/AIDS dengan Stigma terhadap Orang dengan HIV/AIDS di Kalangan Remaja 15-19 Tahun di Indonesia (Analisis Data SDKI Tahun 2012). Jurnal Epidemologi Kesehatan Indonesia.2017 Vol.1 No.2

Singarimbun, Masri dan Sofian Effendi. 2011. Metode Penelitian Survai. Jakarta: LP3ES

Siregar, Syofian. 2011. Statistika Deskriptif untuk Penelitian Dilengkapi Perhitungan Manual dan Aplikasi SPSS Versi 17. Jakarta: PT RajaGrafindo Persada

Sugiyono. 2008. Metode Penelitian Kuantitatif Kualitatif dan R\&D. Bandung: Alfabeta

Sutopo. 2010. Penentuan Jumlah Sampel dalam Penelitian dalam e-jurnal STIE Dharma Putra Semarang

Urifah, Siti. 2017. Pengetahuan dan Stigma terhadap Pasien HIV/AIDS Di Lingkungan Kesehatan, Indonesia. The Indonesian Journal of Health Science.Vol.8 No.2. Juni 2017 